\title{
Pengaruh Model Generative Learning Terhadap Hasil Belajar Ranah Kognitif Siswa Pada Materi Hukum Newton
}

\author{
Haris Rosdianto \\ Sekolah Tinggi Keguruan dan Ilmu Pendidikan (STKIP) Singkawang \\ Email: harisrosdianto@yahoo.com
}

Received May 21, 2017; Revised July 25, 2017; Accepted September 11, 2017

\begin{abstract}
Abstrak
Penelitian ini bertujuan untuk mengetahui pengaruh model generative learning terhadap hasil belajar ranah kognitif siswa pada materi Hukum Newton. Jenis penelitian ini adalah penelitian pre eksprimental dengan rancangan One Group Pretest Posttest Design. Populasi penelitian ini adalah seluruh siswa kelas VIII MTs Makarim Al-akhlak Kota Singkawang. Dikarenakan kelas VIII hanya terdiri atas satu kelas, maka teknik sampling yang digunakan adalah sampling jenuh. Instrumen penelitian yang digunakan berupa tes pilihan ganda. Data dianalisis dengan menggunakan uji paired $t$ test. Dari hasil perhitungan diperoleh nilai $-\mathrm{t}_{\text {hitung }}<-\mathrm{t}_{\text {tabel }}$ yaitu $-18,03<-2,160$, maka $\mathrm{H}_{0}$ ditolak dan $\mathrm{H}_{\mathrm{a}}$ diterima pada taraf signifikansi $\alpha=0,05$. Sehingga dapat disimpulkan bahwa terdapat pengaruh model generative learning terhadap hasil belajar ranah kognitif siswa pada materi Hukum Newton.
\end{abstract}

Kata kunci: Generative Learning, Hasil Belajar Ranah Kognitif, Hukum Newton

\section{The Effect of Generative Learning Model on Students' Cognitive Learning Outcomes In Newton's Law}

\begin{abstract}
This study aims to determine the effect of generative learning model on the students' cognitive learning outcomes in Newton's Law. This type of research is pre experimental study with One Group Pretest Posttest Design. The population of this research is all students of class VIII MTs Makarim Alakhlak Singkawang. Since class VIII consists of only one class, the sampling technique used is saturated sampling. The research instrument used in the form of multiple choice test. Data were analyzed by using paired $t$-test. From the calculation results obtained value $-t_{\text {count }}<-t_{\text {table }}$ ie $-18.03<-$ 2,160 , then $H_{0}$ rejected and $H_{a}$ accepted at the level of significance $\alpha=0.05$. So it can be concluded that there is influence of generative learning model to cognitive student learning outcomes on Newton's Law.
\end{abstract}

Keywords: Generative Learning, Cognitive Learning Outcomes, Newton's Law

DOI : 10.25273/jpfk.v3i2.1288

\section{PENDAHULUAN}

Pelajaran fisika hingga saat ini masih dianggap sebagai salah satu pelajaran yang paling sulit untuk dipelajari di antara pelajaran IPA lainnya. Pernyataan ini sering dilontarkan oleh siswa tingkat SMP. Hal ini dikarenakan siswa merasa selain dituntut untuk memahami konsep-konsep yang ada, juga dituntut untuk mampu menggunakan rumus-rumus matematika untuk menyelesaikan soal-soal fisika (Simanjuntak, 2013). Salah satu materi fisika yang sulit dipelajari oleh siswa adalah materi
Hukum Newton (Pohan \& Simamora, 2014). Siswa juga sering merasa jenuh dan bosan dengan pembelajaran yang berpusat pada guru. Guru cenderung menggunakan model konvensional dengan metode ceramah, tanya jawab, dan penugasan sehingga siswa hanya bisa menulis dan mencatat apa yang didengar dan dijelaskan oleh gurunya, tanpa dilibatkan langsung dalam proses menemukan dan mengembangkan pengetahuan sesuai dengan kemampuannya sendiri. Padahal setiap siswa merupakan subjek dalam proses belajar mengajar yang memiliki karakteristik yang

Copyright (C) 2017, Jurnal Pendidikan Fisika dan Keilmuan(JPFK)

Avaliable online at: http://e-journal.unipma.ac.id/index.php/JPFK

Print ISSN: 2442-8868, Online ISSN: 2442-904X 
berbeda satu sama lain. Ada anak yang cepat tanggap, mudah mengerti, ada pula yang lambat menerima (Tambunan \& Siregar, 2014).

Berdasarkan hasil wawancara dengan guru IPA MTs Makarim Al-akhlak Kota Singkawang menunjukkan bahwa siswa kurang aktif dalam mengajukan pertanyaan ataupun saran pelaksanaan saat pembelajaran di kelas, sehingga mengakibatkan hasil belajar siswa rendah. Hal ini terlihat dari skor rata-rata ulangan harian IPA yang hanya mencapai 57, sedangkan skor Kriteria Ketuntasan Minimal (KKM) pada mata pelajaran IPA adalah 65.

Salah satu faktor yang mempengaruhi rendahnya hasil belajar siswa adalah proses pembelajaran. Pembelajaran fisika yang dilaksanakan oleh guru masih menganut pada teori tabula rasa John Locke, yang menyatakan bahwa pikiran seorang anak adalah seperti kertas kosong yang putih bersih dan siap menunggu coretan-coretan gurunya. Dengan kata lain, otak seorang anak adalah ibarat botol kosong yang siap diisi dengan segala ilmu pengetahuan dan kebijaksanaan dari guru (Sardiman, 2001). Dengan pembelajaran tersebut siswa bagaikan klise orang dewasa yang pasif dan memerlukan motivasi dari luar. Guru mengembangkan kurikulum yang terstruktur dan menentukan bagaimana siswa harus dimotivasi, dirangsang dan dievaluasi sehingga terkesan pembelajaran adalah sekedar pemindahan dan penyerapan pengetahuan sehingga dirasakan kurang bermakna bagi siswa. Dalam mengikuti pembelajaran, siswa cenderung lebih senang mengikuti perintah guru, sehingga membuat siswa cenderung kurang aktif.

Oleh karena itu, diperlukan model pembelajaran yang dapat meningkatkan hasil belajar siswa. Satu di antara model pembelajaran yang bisa digunakan adalah model generative learning. Esensi pembelajaran generatif adalah pikiran atau otak manusia bukanlah penerima informasi secara pasif tetapi aktif mengkonstruksi dan menafsirkan informasi dan selanjutnya menarik kesimpulan berdasarkan informasi tersebut (Osborne \& Wittrock, 1985). Pembelajaran generatif melibatkan aktivitas mental berpikir (Ritchie \& Volkl, 2000). Mental berpikir seseorang yang melakukan pembelajaran generatif akan berjalan sejalan proses belajarnya (Flick, 1996).

Berdasarkan uraian di atas, maka peneliti tertarik melakukan penelitian dengan judul
"Pengaruh Model Generative Learning Terhadap Hasil Belajar Ranah Kognitif Siswa Pada Materi Hukum Newton". Melalui model pembelajaran ini diharapkan dapat meningkatkan hasil belajar siswa dan dapat digunakan sebagai alternatif untuk pembelajaran fisika secara terus menerus.

\section{METODE}

\section{Jenis dan Desain Penelitian}

Jenis penelitian yang digunakan dalam penelitian ini adalah penelitian kuantitatif. Metode yang digunakan adalah pre experimental design. Desain penelitian ini adalah one group pretest posttest design. Populasi penelitian ini adalah seluruh siswa kelas VIII MTs Makarim $\mathrm{Al}$-akhlak Kota Singkawang. Dikarenakan kelas VIII hanya terdiri atas satu kelas, maka teknik sampling yang digunakan adalah teknik nonprobability sampling berupa sampling jenuh. Sampling jenuh digunakan karena semua anggota populasi digunakan sebagai sampel penelitian (Sugiyono, 2012).

Variabel dalam penelitian ini terdiri dari variabel bebas dan variabel terikat. Variabel bebas dalam penelitian ini adalah model generative learning, sedangkan variabel terikatnya adalah hasil belajar ranah kognitif siswa. Tes yang digunakan berupa pilihan ganda sebanyak 15 butir soal untuk mengetahui hasil belajar ranah kognitif siswa. Instrumen pengumpulan data yang digunakan adalah lembar pretest dan posttest. Sebelum tes digunakan dalam penelitian, terlebih dahulu dilakukan uji coba (Arikunto, 2010). Data hasil uji coba instrumen kemudian diolah atau dianalisis.

\section{Teknik Analisis Data}

\section{Uji Normalitas Data}

Untuk pengujian normalitas data, digunakan uji Chi-kuadrat (Sugiyono, 2007) yaitu seperti pada persamaan 1 .

$\chi^{2}=\sum_{i=1}^{k} \frac{(f o-f \theta)^{2}}{f \theta}$

Di mana fo adalah frekuensi observasi dan fe adalah frekuensi harapan. Kriteria pengujian yang digunakan pada $\mathrm{db}=(\mathrm{k}-3)$ dengan taraf signifikansi $\alpha=0,05$ adalah jika $\chi^{2}$ hitung $<\chi_{\text {tabel, }}^{2}$, maka data dikatakan berasal dari populasi yang berdistribusi normal. 

Print ISSN: 2442-8868, Online ISSN: 2442-904X

\section{Uji Hipotesis}

Untuk mengetahui seberapa jauh hipotesis yang telah dirumuskan didukung oleh data yang dikumpulkan, maka hipotesis tersebut harus diuji. Jika sebaran data berdistribusi normal, maka data yang diperoleh dianalisis dengan menggunakan uji paired t-test (Sugiyono, 2007) dengan pasangan hipotesis adalah:

$\mathrm{H}_{0}$ : Tidak terdapat pengaruh model generative learning terhadap hasil belajar ranah kognitif siswa pada materi Hukum Newton

$\mathrm{H}_{\mathrm{a}}$ : Terdapat pengaruh model generative learning terhadap hasil belajar ranah kognitif siswa pada materi Hukum Newton. Rumus yang digunakan adalah:

$$
t_{\text {hitung }}=\frac{X-Y}{\sqrt{\frac{S_{x x}{ }^{2}}{n_{x}}+\frac{S_{y}{ }^{2}}{n_{y}}-2 r\left(\frac{S_{x}}{\sqrt{n_{x}}}\right)\left(\frac{S_{y}}{\sqrt{n_{y}}}\right)}}
$$

dengan kriteria pengujian yakni $\mathrm{H}_{0}$ diterima jika $t_{\text {hitung }} \leq t_{\text {tabel }}$ pada taraf signifikansi $\alpha=0,05$ dan $\mathrm{db}=(\mathrm{n}-1)$ serta untuk harga $\mathrm{t}$ lainnya $\mathrm{H}_{0}$ di tolak. Namun, jika sebaran data yang diperoleh tidak normal maka digunakan uji statistik nonparametrik (Sugiyono, 2007).

\section{HASIL DAN PEMBAHASAN}

Data yang disajikan dalam penelitian ini adalah data yang diperoleh dari hasil tes berupa pretest dan postest. Data hasil yang diperoleh siswa yang dapat dilihat pada tabel 1 .

Tabel 1. Hasil pretest dan posttest

\begin{tabular}{cccc}
\hline & Pretest & Posttest & Selisih \\
\hline Nilai rata-rata & 47,50 & 66,67 & 19,17 \\
Standar Deviasi & 6,60 & 6,66 & \\
Nilai tertinggi & 60 & 80 & \\
Nilai terendah & 33,33 & 53,33 & \\
\hline
\end{tabular}

Berdasarkan tabel 1 dapat dilihat bahwa nilai rata-rata hasil posttest sebesar 66,67 lebih tinggi dari hasil pretest sebesar 47,50. Hal ini menunjukkan bahwa hasil belajar ranah kognitif siswa meningkat setelah diberikan perlakuan dengan menggunakan model generative learning.
Setelah seluruh data diperoleh, tahapan selanjutnya adalah menganalisis data. Langkah pertama adalah melakukan uji normalitas data yang bertujuan untuk mengukur apakah data yang dianalisis berdistribusi normal sehingga dapat digunakan dalam statistik parametrik. Rangkuman hasil uji normalitas data pretest dan posttest dapat dilihat pada tabel 2.

Tabel 2 Rangkuman uji normalitas data pretest dan posttest

\begin{tabular}{ccccc}
\hline $\begin{array}{c}\text { Nilai } \chi_{\text {hitung }}^{2} \\
\text { pretest }\end{array}$ & $\begin{array}{c}\text { vilai } \chi_{\text {tabel }}^{2} \\
\text { pretest }\end{array}$ & $\begin{array}{c}\text { Nilai } \chi^{2}{ }_{\text {hitung }} \text { Nilai } \chi_{\text {tabel }}^{2} \\
\text { posttest }\end{array}$ & $\begin{array}{c}\text { Uji } \\
\text { posttest }\end{array}$ & Normalitas \\
\hline 1,88 & 5,991 & 0,53 & 5,991 & Normal \\
\hline
\end{tabular}

Dari tabel 2 diperoleh bahwa nilai pretest dan posttest siswa berdistribusi normal. Setelah data dipastikan berdistribusi normal, selanjutnya dilakukan uji statistik parametrik paired t-test. Dari hasil perhitungan diperoleh nilai $-t_{\text {hitung }}<-$ $\mathrm{t}_{\text {tabel }}$ yaitu $-18,03<-2,160$, maka $\mathrm{H}_{0}$ ditolak dan $\mathrm{H}_{\mathrm{a}}$ diterima pada taraf signifikansi $\alpha=0,05$.

Dari hasil penelitian menunjukkan bahwa terdapat pengaruh model generative learning terhadap hasil belajar siswa pada materi Hukum
Newton di kelas VIII MTs Makarim Al-akhlak Kota Singkawang, dibuktikan dengan perolehan nilai rata-rata pretest siswa sebesar 47,50 dan nilai rata-rata postest sebesar 66,67 . Ini juga dibuktikan dari uji statistik untuk menguji hipotesis penelitian dan diperoleh nilai $-\mathrm{t}_{\text {hitung }}<-$ $\mathrm{t}_{\text {tabel }}$ yaitu $-18,03<-2,160$, maka $\mathrm{H}_{0}$ ditolak dan $\mathrm{H}_{\mathrm{a}}$ diterima pada taraf signifikansi $\alpha=0,05$. Hal ini didukung oleh Osborne \& Wittrock (1985) yang menyatakan bahwa model generative 
learning memberikan pengaruh yang signifikan terhadap pencapaian hasil belajar. Hal ini juga didukung oleh Ritchie \& Volkl (2000) yang menyatakan bahwa penerapan model generative learning efektif dalam meningkatkan hasil belajar.

\section{KESIMPULAN}

Berdasarkan hasil dan pembahasan yang dilakukan dapat disimpulkan terdapat peningkatan hasil belajar siswa kelas VIII MTs Makarim Al-akhlak Kota Singkawang pada materi Hukum Newton setelah diterapkan model generative learning. Hal ini dapat dilihat dari nilai rata-rata hasil belajar siswa sebelum diberi perlakuan (pretest) sebesar 47,50, dan setelah diberi perlakuan (posttest) sebesar 66,67.

Terdapat pengaruh model generative learning terhadap hasil belajar ranah kognitif siswa di kelas VIII MTs Makarim Al-akhlak Kota Singkawang pada materi Hukum Newton. Hal ini dapat dilihat dari uji hipotesis di mana nilai $-\mathrm{t}_{\text {hitung }}<-\mathrm{t}_{\text {tabel }}$ yaitu $-18,03<-2,160$ dengan taraf signifikansi sebesar 5\%.

\section{DAFTAR PUSTAKA}

Arikunto, S. (2010). Dasar-dasar Evaluasi Pendidikan (Edisi Revisi) (11th ed.). Jakarta: Bumi Aksara.

Flick, L. B. (1996). Understanding a generative learning model of instruction: A case study of elementary teacher planning. Journal of Science Teacher Education, $7(2)$, 95-122. https://doi.org/10.1007/BF00114121

Osborne, R., \& Wittrock, M. (1985). The Generative Learning Model and its Implications for Science Education.
Studies in Science Education, 12(1), 5987.

https://doi.org/10.1080/0305726850855 9923

Pohan, D. \& Simamora, P. (2014). Pengaruh Model Pembelajaran Kooperatif Tipe Jigsaw Berbasis Macromedia Flash Terhadap Hasil Belajar Siswa Pada Materi Pokok Hukum-hukum Newton. Jurnal INPAFI, 2(3), 45-53.

Ritchie, D., \& Volkl, C. (2000). Effectiveness of Two Generative Learning Strategies in the Science Classroom. School Science and Mathematics, 100(2), 83-89. https://doi.org/10.1111/j.19498594.2000.tb17240.x

Sardiman A. M. (2001). Interaksi dan Motivasi Belajar Mengajar. Jakarta: Raja Grafindo Persada.

Simanjuntak, M. P. (2013). Implementasi Model Pembelajaran Kooperatif Tipe NHT Terhadap Hasil Belajar Siswa SMP Pada Materi Gaya dan Hukum Newton T.P 2012/2013. Jurnal INPAFI, 1(2), 107-113.

Sugiyono. (2007). Statistika Untuk Penelitian (12th ed.). Bandung: Alfabeta.

Sugiyono. (2012). Metode Penelitian Kuantitatif, Kualitatif dan $R \& D$ (16th ed.). Bandung: Alfabeta.

Tambunan, D. S. \& Siregar, A. M. (2014). Pengaruh Model Pembelajaran Berbasis Masalah dengan Menggunakan Media Kartun Terhadap Hasil Belajar Siswa Pada Materi Pokok Gaya dan Hukum Newton di Kelas VIII SMP Swasta AnNizam Medan Tahun Pelajaran 2013/2014. Jurnal INPAFI, 2(3), 28-37. 